\title{
Aplikasi Pendataan Lokasi Bank, ATM, dan SPBU di Kota Padang Berbasis Android
}

\author{
Elizamiharti ${ }^{1}$, Amuharnis ${ }^{2}$, indri yeni ${ }^{3}$, Ardarini Rahmadani ${ }^{4}$ \\ Sistem Informasi, STMIK Indonesia Padang ${ }^{1,2,4}$, Sistem Informasi, UPI YPTK ${ }^{3}$ \\ Email: elizamiharti2@gmail.com ${ }^{1}$, amp.sati@gmail.com ${ }^{2}$, indriyeni@gmail.com³, \\ ardarinirahmadani@gmail.com ${ }^{4}$ \\ DOI: http://dx.doi.org/10.31869/rtj.v4i1.2218
}

\begin{abstract}
Abstrak :Padang city is the capital of West Sumatera province which is developing in various fields, one of them is banking field. The amount of ATM distribution makes people difficult to memorize and know where the ATM location. Likewise with gas stations, many of the community, immigrants and tourists who do not know the location of the city Padang SPBU in the city of Padang. Through the design and development of location-based mobile data collection applications android this can facilitate the community, immigrants and tourists in finding information on the location of banks, ATMs and gas stations in the city of Padang. The method used is the method of data collection and survey analysis, while the design method using SDLC method with waterfall model. This application uses haversine formula as a calculation method that is considered suitable for nearest location search because in the calculation process to take into account the curvature of the earth so it can produce more accurate results. With this application android phone users can find out the location of banks, ATMs and gas stations that are closest to where they are located.
\end{abstract}

Keywords: Padang city, Android, waterfall, Bank, ATM, SPBU.l

Abstract :Kota Padang merupakan ibukota Provinsi Sumatera Barat yang sedang berkembang di berbagai bidang, salah satunya adalah bidang perbankan. Banyaknya sebaran ATM membuat masyarakat kesulitan menghafal dan mengetahui dimana lokasi ATM tersebut. Begitupun dengan SPBU, banyak dari masyarakat pendatang dan wisatawan kota Padang yang tidak mengetahui lokasi SPBU yang ada di kota Padang. Melalui perancangan dan pembangunan aplikasi pendataan lokasi berbasis mobile android ini dapat mempermudah masyarakat, pendatang dan wisatawan dalam mencari informasi lokasi bank, ATM dan SPBU yang ada di Kota Padang.Metode yang digunakan adalah dengan metode analisis pengumpulan data dan survei, sedangkan metode perancangan menggunakan metode SDLC dengan model waterfall.Aplikasi ini menggunakan haversine formula sebagai metode perhitungan yang dinilai sesuai untuk pencarian lokasi terdekat karena dalam proses perhitungannya memperhitungkan kelengkungan bumi sehingga dapat membuahkan hasil yang lebih akurat. Dengan aplikasi ini pengguna ponsel android dapat mengetahui lokasi bank, ATM dan SPBU yang terdekat dari lokasi mereka berada

Kata Kunci: Padang city, Android, waterfall, Bank, ATM, SPBU.

\section{PENDAHULUAN}

Teknologi informasi dan komunikasi di dunia berkembang setiap waktu, salah satu contohnya pada telepon genggam.Terobosan baru pada telepon genggam ditandai dengan munculnya suatu sistem operasi yaitu Android.Android adalah sebuah sistem operasi perangkat mobile berbasis linux yang mencangkup sistem operasi, middleware dan aplikasi. Android menyediakan platform terbuka bagi para pengembang untuk menciptakan aplikasi mereka (Juansyah, 2015). Salah satu teknologi yang terdapat pada perangkat ponsel Android saat ini adalah GPS (Global Positioning System) yaitu teknologi navigasi yang memanfaatkan satelit. Dengan menggunakan fasilitas GPS ini pengguna ponsel Android akan mendapatkan informasi posisi dan waktu dengan akurasi yang sangat tinggi.
Android sebagai sistem operasi berbasis linux dapat digunakan di berbagai perangkat mobile.Hingga saat ini Android terus berkembang, baik secara sistem maupun aplikasinya.

Kota Padang merupakan ibukota provinsi Sumatera Barat yang sedang berkembang di berbagai bidang, salah satunya adalah bidang perbankan. Di Kota Padang banyak terdapat lembaga perbankan yang dilengkapi beberapa unit Anjungan Tunai Mandiri (ATM). Persebaran ATM di kota Padang sangat banyak, dan tidak sedikit dari para nasabah yang belum mengetahui lokasi ATM di wilayah tersebut. Penempatan lokasi ATM biasanya hanya di tempat keramaian, seperti di bank, instansi pemerintah, hotel, tempat perbelanjaan. Banyak ATM yang dikunjungi oleh nasabah setiap harinya dan banyak pula ATM yang terlihat sepi disebabkan 
oleh beberapa hal, seperti terlalu jauh lokasi ATM dari tempat tinggal dan tempat kerja nasabah ataupun kekurangnyamanan nasabah dalam bertransaksi melalui ATM. Minimnya informasi dan belum adanya aplikasi tentang persebaran Bank dan ATM membuat nasabah mengalami kesulitan saat mencari jarak lokasi Bank dan ATM yang terdekat dengan keberadaan mereka.

SPBU (Stasiun Pengisian Bahan Bakar Umum) merupakan tempat pengisian bahan bakar untuk kendaraan bermotor seperti premium, solar, pertalite maupun pertamax.

SPBU dapat menjadi tempat yang paling dibutuhkan oleh pengguna kendaraan bermotor ketika bahan bakar kendaraan telah menipis.Sementara itu, saat bepergian dengan kendaraan bermotor banyak orang merasa kesulitan untuk mencari informasi lokasi SPBU terdekat. Hal ini tentunya tidak menjadi masalah jika orang tersebut sudah mengenal lokasi dengan baik, akan tetapi bagi orang yang tidak mengenal lokasi akan menjadi suatu kendala. Bahkan dapat menjadi masalah yang merepotkan jika kendaraan sampai mogok karena tidak tahu lokasi SPBU terdekat.Berdasarkan uraian di atas, maka dibutuhkan sebuah sistem yang dapat menunjukkan sebaran Bank, ATM, dan SPBU secara geografis.Oleh karena itu, penulis membahas dalam bentuk penelitian yang berjudul "Aplikasi Pendataan Lokasi Bank, ATM, dan SPBU di Kota Padang Berbasis Android".

\section{TINJAUAN PUSTAKA}

\section{Pengertian Aplikasi}

Aplikasi adalah suatu program yang siap untuk digunakan yang dibuat untuk melaksanankan suatu fungsi bagi pengguna jasa aplikasi serta penggunaan aplikasi lain yang dapat digunakan oleh suatu sasaran yang akan dituju (Juansyah, 2015).Aplikasi mempunyai arti yaitu pemecahan masalah yang menggunakan salah satu tehnik pemrosesan data aplikasi yang biasanya berpacu pada sebuah komputansi yang diinginkan atau diharapkan maupun pemrosesan data yang diharapkan. Pengertian (Abdurahman \& Riswaya, 2014).Jadi, dapat disimpulkan bahwa aplikasi adalah program siap pakai yang digunakan oleh pengguna aplikasi untuk mendapatkan hasil yang diinginkan dan sasaran yang dituju.

2. Bank dan ATM

Menurut Thamrin Abdullah dan Francis Tantri (2012:5) Bank adalah suatu jenis lembaga keuangan yang melaksanakan berbagai macam jasa, seperti memberikan pinjaman, mengedarkan mata uang, pengawasan terhadap mata uang, bertindak sebagai tempat penyimpanan benda-benda berharga, membiayai usaha perusahaan-perusahaan dan lainlain.ATM adalah suatu alat yang berfungsi untuk mengeluarkan uang kepada pemegang kartu ATM sebagai alternatif pengganti pengambilan uang di bank yang mengeluarkan ATM. Setiap pemilik kartu ATM memiliki Personal Identification Number (PIN) yaitu nomor identifikasi untuk seorang nasabah pemegang kartu ATM dan hanya yang bersangkutan sendiri yang mengetahuinya. ATM itu sendiri merupakan mesin yang dapat melayani kebutuhan nasabah secara otomatis setiap saat selama 24 jam dan 7 hari atau satu minggu termasuk hari libur (Eviliyanto, 2014).

\section{Analytical Hierarchy Process}

Stasiun pengisian bahan bakar adalah tempat di mana kendaraan bermotor dapat memperoleh bahan bakar. Di Indonesia, Stasiun Pengisian Bahan Bakar dikenal dengan nama SPBU (Stasiun Pengisian Bahan Bakar Umum). Namun, masyarakat juga memiliki sebutan lagi bagi SPBU, misalnya di kebanyakan daerah, SPBU disebut Pom Bensin yang adalah singkatan dari Pompa Bensin (Hartono \& Sevani, 2013).

\section{Android}

Menurut Zuhara (2016:8) "Android adalah sistem operasi berbasis Linux yang dimodifikasi untuk perangkat bergerak (mobile devices) yang terdiri dari sistem operasi, middleware, dan aplikasiaplikasi utama. Awalnya, Android dikembangkan oleh Android Inc. Perusahaan ini kemudian dibeli Google pada tahun 2005.Sistem operasi Android diluncurkan bersamaan dengan dibentuknya organisasi Open Handset Alliance tahun 2007. Selain Google, beberapa nama-nama besar juga ikut serta dalam Open Handset Alliance, antara lain Motorola, Samsung, LG, Sony Ericsson, T-Mobile, Vodafone, Toshiba, dan Intel".

\section{METODE PENELITIAN}

Pada penelitian ini selain menggunakan metode penulisan, penulis juga menggunakan metode pengembangan perangkat lunak untuk membuat aplikasi pendataan lokasi bank, ATM dan SPBU di Kota Padang berbasis android, adapun metode yang digunakan adalah SDLC (Systems Development Life Cycle) dengan model Waterfall yang disadur dari buku Sukamto dan Shalahuddin tahun 2013 (Firmansyah, 2018). Adapun penjelasan dari metode ini adalah sebagai berikut: 


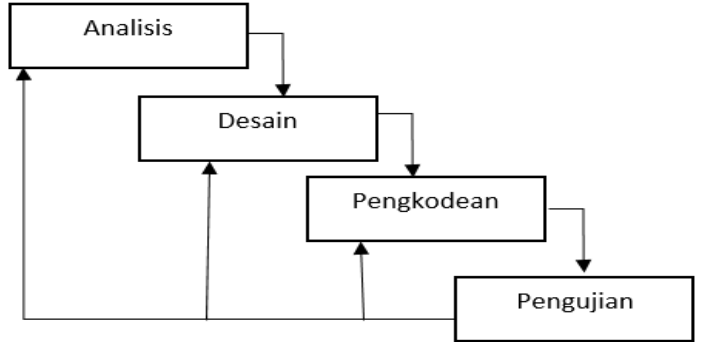

Gambar 1. Kerangka Kerja Penyelesaian Pengembangan Sistem

a. Analisis yaitu menganalisis kebutuhan masyarakat lokal, pendatang maupun wisatawan dengan tujuan untuk mendapatkan jawaban dan mengetahui permasalahanpermasalahan yang sering dihadapi pada saat mencari lokasi bank, ATM dan SPBU terdekat di Kota Padang saat dibutuhkan.

b. Desain yaitu menterjemahkan syarat kebutuhan ke sebuah perancangan perangkat lunak yang dapat diperkirakan sebelum diimplementasikan. Proses ini berfokus pada detail prosedural (flowchart \& Diagram), arsitektur perangkat lunak, representasi interface. Mendesain aplikasi baru yang dapat menyelesaikan masalah-masalah yang dihadapi dalam pencarian lokasi bank, ATM dan SPBU di Kota Padang.

c. Pengkodean yaitu dimana penulis mengimplementasikan perencanaan sistem ke situasi nyata yaitu dengan pemilihan perangkat keras dan penyusunan perangkat lunak aplikasi (pengkodean). Penulis menggunakan aplikasi android studio sebagai software yang mendukung menyelesaikan permasalahan ini.

d. Pengujian yaitu untuk menentukan apakah sistem atau perangkat lunak yang dibuat sudah sesuai dengan kebutuhan pengguna. Tujuan dari pengujian itu adalah untuk menghilangkan dan meminimalisasi cacat program sehingga yang dibuat benar membantu pengguna saat membutuhkan aplikasi ini.

\section{ANALISA DAN HASIL}

Analisis sistem yang sedang berjalan pada Badan Pusat Statistik Kota Padang mengenai pendataan lokasi Bank, ATM dan SPBU di Kota Padang adalah dengan mempelajari sistem yang sedang berjalan atau diterapkan saat ini pada pengolahan data lokasi Bank, ATM dan SPBU di Kota Padang, yang kemudian dianalisis untuk mengetahui perincian sistem secara detail. Setelah dilakukan penelitian, diperoleh keadaan sistem yang digunakan saat ini dan beberapa kelemahan yang ada.

\section{Sistem yang diusulkan}

a. Use Case Diagram Admin

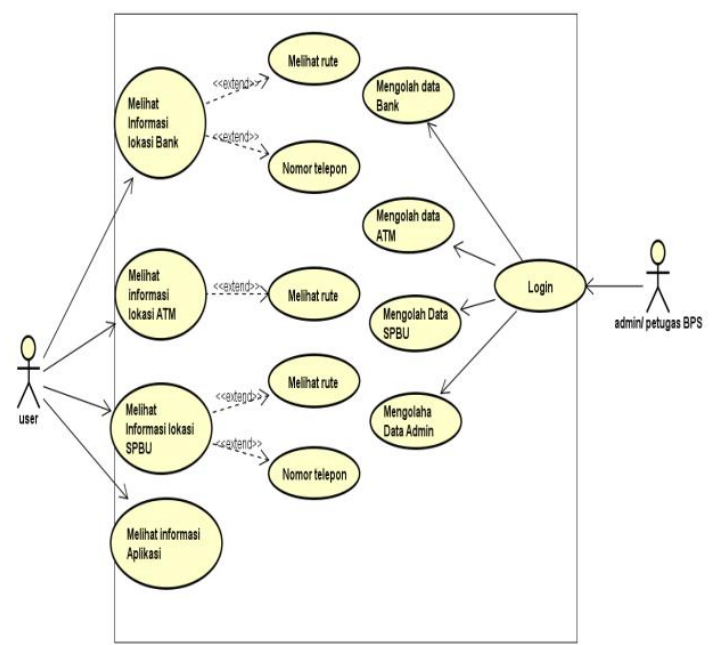

Gambar 2.Use case Diagram user dan admin Use case diagram merupakan pemodelanuntuk kelakuan (behavior) sisteminformasi yang akan dibuat. Use casedigunakan untuk mengetahui fungsiapa saja yang ada di dalam sisteminformasi dan siapa saja yang berhakmenggunakan fungsifungsi tersebut.

\section{b. Activity Diagram Admin}

Diagram Aktivitasmenggambarkanworkflow (aliran kerja) atau aktivitasdari sebuah sistem atau proses bisnis.

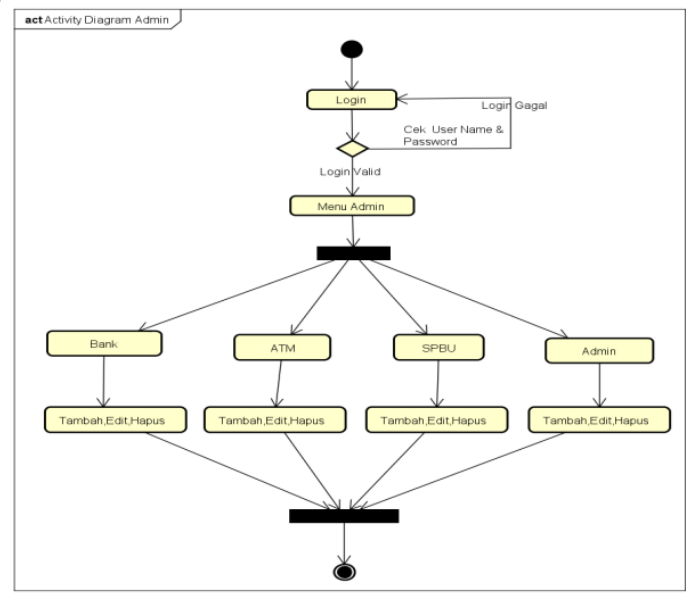

Gambar 3.Activity DiagramAdmin 
c. Activity Diagram User

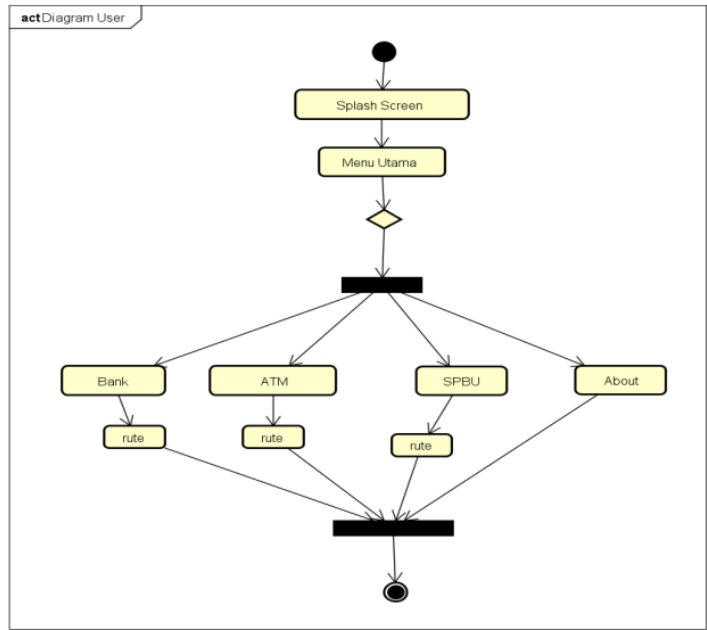

Gambar 4.Activity DiagramKepala Sekolah

\section{d.Class Diagram}

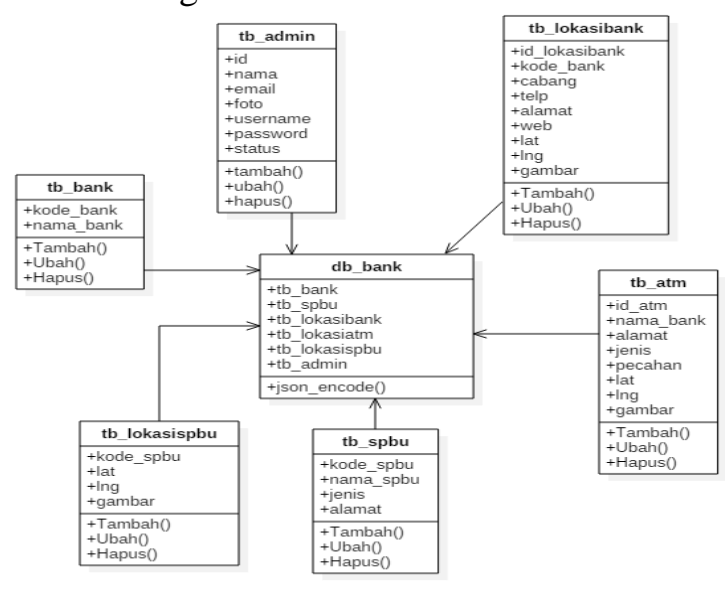

Gambar 5.ClassDiagram

Class Diagram mendefenisikan informasi apa yang dimiliki suatu objek serta mendefinisikan perilaku yang dimilikinya. Class Diagram mengabstraksikan elemen-elemen dari sistem yang sedang dibangun dan dirancang.

Halaman login adalah halaman akses admin untuk dapat masuk ke halaman utama dan memperbaharui informasi mengenai lokasi Bank, ATM dan SPBU di Kota Padang.

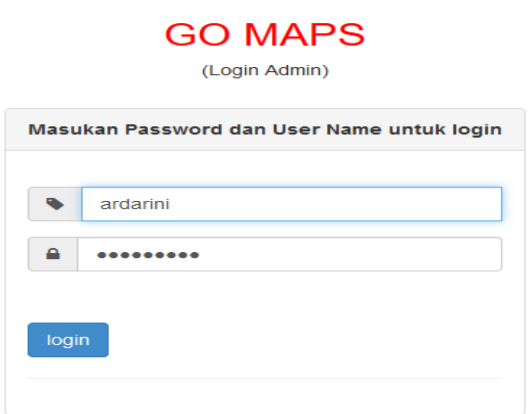

Gambar 6. Halaman Login

b. Input Data Bank

Form input data lokasi Bank berfungsi untuk menambahkan data lokasi Bank, untuk lebih jelasnya dapat dilihat pada Gambar 7.
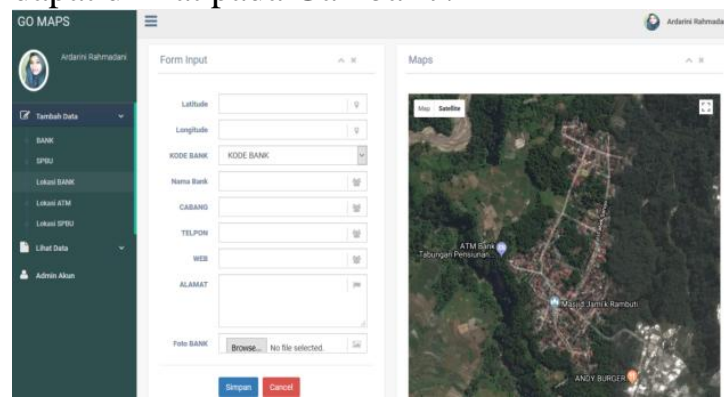

c. Input Data ATM

\section{Gambar 7. Input Data Bank}

Form input data lokasi ATM berfungsi untuk menambahkan data lokasi ATM, untuk lebih jelasnya dapat dilihat pada Gambar 8 .
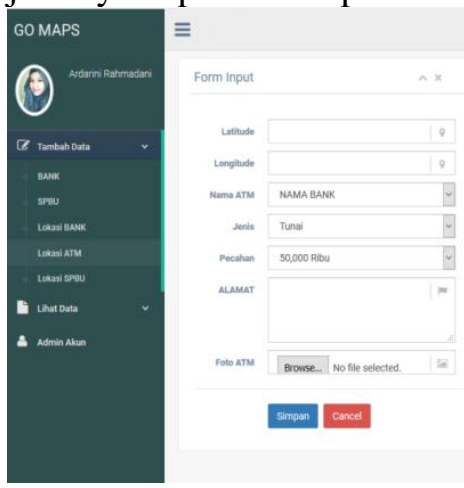

Gambar 8.Input Data ATM

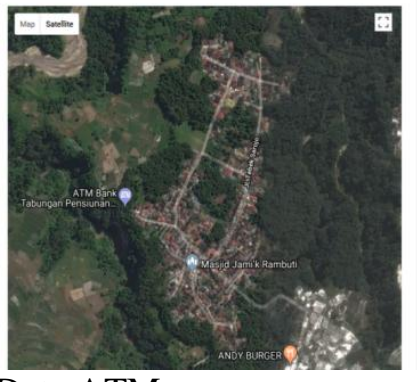

d.Input Data SPBU

Form input data SPBU berfungsi untuk menambahkan data SPBU, untuk lebih jelasnya dapat dilihat pada Gambar 9. 


\begin{tabular}{|ll|}
\hline $\begin{array}{l}\text { Vol. } 4 \text { No.1 Januari } 2021 \\
\text { http://jurnal.umsb.ac.id/index.php/RANGTEKNIKJOURNAL }\end{array}$ & Rang Teknik Journal \\
\hline
\end{tabular}
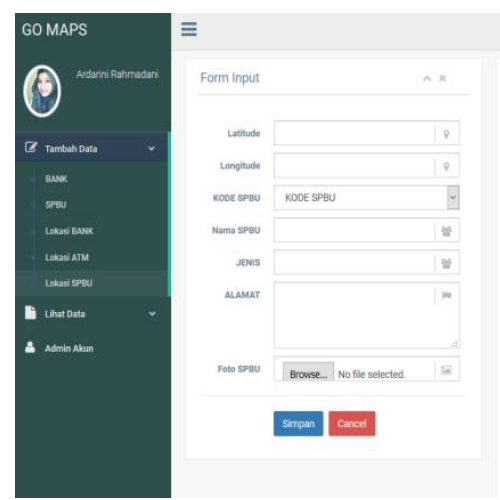

Gambar 9. Input Data SPBU

e. Halaman Menu Utama Aplikasi

Tampilan menu utama merupakan link dari beberapa tampilan kelas pendukung. Kelas pendukung dari menu utama aplikasi ini adalah seperti Bank, ATM, SPBU, danAbout. Tampilan halaman menu utama tersebut dapat dilihat pada Gambar 10.

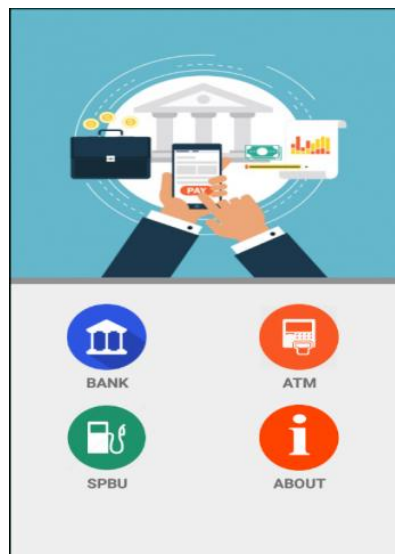

Gambar 10.Halama Menu Utama

f. Halaman Menu Detail Bank

Tampilan menu detail Bank merupakan submenu dari list Bank yang menampilakan nama Bank, alamat, gambar dan terdapat button untuk web dan nomor telepon. Tampilan halaman menu detail Bank dapat dilihat pada Gambar11.

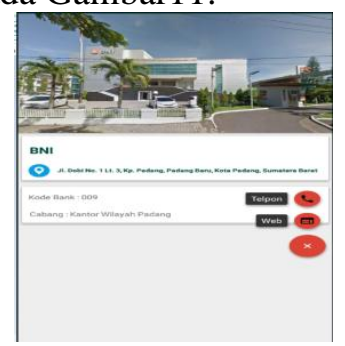

Gambar 11. Halaman Menu Detail Bank g. Halaman Menu Rute

Tampilan peta Rumah Sakit merupakan submenu dari detail Bank yang dapat menampilkan rute ke lokasi Bank beserta estimasi jarak dan waktu ke lokasi Bank. Tampilan halaman peta Bank dapat dilihat pada Gambar 12.

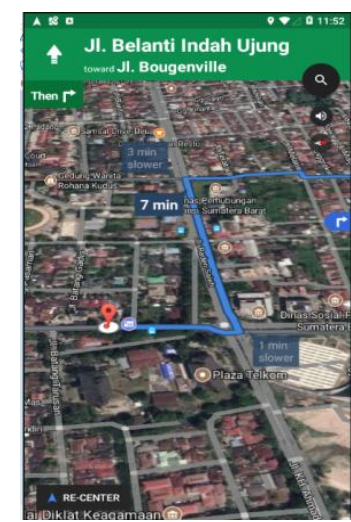

Gambar12. Halaman Menu Rute

\section{Simpulan}

Berdasarkan hasil analisis dan pembahasan babbab sebelumnya yang dilakukan pada Bank, ATM dan SPBU yang ada di kota Padang, maka dapat diambilkan kesimpulan sebagai berikut:

1. Dengan adanya aplikasi pendataan lokasi Bank, ATM dan SPBU di kota Padang berbasis android ini, dapat membantu dan memudahkan pendatang, wisatawan dan masyarakat lokal dalam pencarian lokasi Bank, ATM dan SPBU yang terdekat dan yang ingin dituju pengguna.

2. Dengan adanya perancangan dan pembangunan aplikasi ini memudahkan pengguna mengetahui informasi lokasi Bank, ATM dan SPBU dengan ketersediaan informasi lokasi-lokasi Bank, ATM dan SPBU di kota Padang khususnya berbasis android.

3. Dengan adanya aplikasi pendataan lokasi Bank, ATM dan SPBU di kota Padang berbasis android, dapat menghemat waktu pengguna dalam pencarian lokasi yang akan dituju.

\section{UCAPAN TERIMAKASIH}

Berisi ucapan terima kasih kepada lembaga LPPM STMIK Indonesia Padang dan juga kepada Kepala Sekolah SMA N 14 Padangyang telah membantu dalam pelaksanaan penelitian tersebut

\section{DAFTAR PUSTAKA}

Abdurahman, H., \& Ririh Riswaya, A. (2014). Aplikasi Pinjaman Pembayaran Secara Kredit Pada Bank Yudha Bhakti, 8(2), 61-69.

Agusvianto, H. (2017). Sistem Informasi Inventori Gudang Untuk Mengontrol Persediaan Barang Pada Gudang Studi Kasus: PT . Alaisys Sidoarjo, $1,40-46$.

Amir, A., \& Isnanto, B. (2014). Prototipe aplikasi untuk mengetahui tata letak atm di pangkalpinang pada smartphone android, 1 (September), 1-6.

Aprianti, W., \& Maliha, U. (2016). Sistem Informasi Kepadatan Penduduk Kelurahan Atau Desa Studi Kasus Pada Kecamatan Bati-Bati, 2(2013), 21- 
28.

Eviliyanto. (2014). Anjungan tunai mandiri (atm) perbankan di kota surakarta, (88).

Firmansyah, Y., \& Udi. (2018). Penerapan Metode SDLC Waterfall Dalam Pembuatan Sistem Informasi Akademik Berbasis Web Studi Kasus Pondok Pesantren Al-Habi Sholeh Kabupaten Kubu Raya, Kalimantan Barat, 4(1).

Hanif Al Fatta, R. M. (2015). Analisis Pengembangan dan Perancangan Sistem Informasi Akademik Smart Berbasis Cloud Computing pada Sekolah Menengah Umum Negeri (SMUN) di Daerah Istimewa Yogyakarta, $8(2), 63-91$.

Hartono, F., \& Sevani, N. (2013). Aplikasi Navigasi Lokasi Pom Bensin Di Jakarta. Teknik Dan Ilmu Komputer, 2(8), 85-95.

Hendini, A. (2016). Pemodelan Uml Sistem Informasi Monitoring Penjualan Dan Stok Barang (Studi Kasus: Distro Zhezha Pontianak), IV(2), 107-116.

Ida Bagus Made yogie Adynyana, R. E. (2012). Persebaran Lokasi Obyek Pariwisata Berbasis Web Dan Mobile Android.

Iswandy, E. (2015). Jurnal Teknoif ISSN : 23382724 Sistem Penunjang Keputusan Untuk Menentukan Penerimaan Mahasiswa Dan Pelajar Kurang Mampu Vol . 3 No . 2 Oktober 2015 Jurnal TEKNOIF ISSN : 2338-2724, 3(2).

Juansyah, A. (2015). Pembangunan Aplikasi Child Tracker Berbasis Assisted - Global Positioning System ( A-Gps ) Dengan Platform Android Jurnal Ilmiah Komputer dan Informatika (Komputa), 1 .

Kosasi, S. (n.d.). Perancangan Sistem Informasi Geografis Mendirikan Stasiun Pengisian Bahan Bakar Umum Design of Geografic Information System in Establishing Gas Station, 167-178.

Layona, R., \& Yulianto, B. (2018). Tempat Makan Pada Perangkat Mobile, 2(2), 9-16.

Listyawati, I. H. (2017). Pengaruh lokasi, kelengkapan produk, kualitas produk dan promosi terhadap keputusan beli konsumen di pamella empat yogyakarta, $I V(2), 50-59$.

Marlena, D., \& Aspriyono, H. (2014). Sistem Informasi Geografis Letak Lokasi Rumah Sakit Dan Apotek Kota Bengkulu Berbasis Android, 10(2), 161-167.

Nugraha, F. (2014). Analisa dan perancangan sistem informasi perpustakaan, 5(1), 27-32.

Pauziah, U. (2013). Perancangan Sistem Pendataan Penduduk Pada Kelurahan Cililitan Jakarta Timur Berbazis Delphi, 6(3), 189-199.

Purmadipta, B., Anra, H., Irwansyah, M. A., Studi, P., Informatika, T., Teknik, F., \& Tanjungpura,
U. (2016). Sistem Informasi Geografis Perumahan dan Fasilitas Sosial Terdekat dengan Metode Haversine Formula, 1(1).

Raja, B. H.P. M., N, A. B. P., \& Irwansyah, M. A. (2015). Rancang Bangun Sistem Informasi Geografis Berbasis Web Fasilitas Pelayanan Kesehatan di Kota Pontianak, 1(2).

Susanto, R., \& Andriana, A. D. (2016). Perbandingan Model Waterfall Dan Prototyping. Majalah Unikom, 14(1), 41-46. 